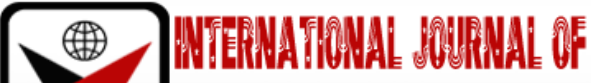

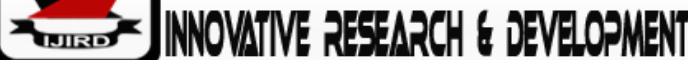

ISSN 2278-0211 (Online)

\section{Entrepreneurial Innovation as Survival Strategy in Family Business}

\author{
Dr. Hasimiyu Ademola Adele \\ Senior Lecturer, Department of Management and Accounting, \\ Ladoke Akintola University of Technology, Nigeria
}

\begin{abstract}
:
The study investigated the contribution of entrepreneurship innovation to the achievement of long-term orientation of family businesses. Specifically, the study examined the various factors contributing to the success of innovative processes in family firms. Primary data collected through the instrumentality of structured questionnaire administered on senior staff of twenty-five (25) purposively selected family firms operating in the southwestern Nigeria, and personal interview on five (5) CEOs also purposively selected were analysed with the aids of descriptive statistics to determine the contribution of each identified variables. Findings revealed that, whereas the popular notion is that family firms are conservative and risk-averse, these attributes are largely responsible for their shrewdness, cautiousness and carefulness in avoiding wasteful investments and ensuring they are very effective and prudent in their innovative processes thereby recording outstanding high innovative output per dollar. The paper concludes that family firms are always able to achieve their long-term ambition only through constant innovative processes.
\end{abstract}

Keywords: Entrepreneurship, family business, innovation, survival, long-term orientation

\section{Introduction}

A prominent feature of family business across context is their long-term orientation and survival instincts. Most family businesses operating all over the world today have been in existence couple of decades now, and this peculiarity does not come easy. This, as attested to by the Small Business Association (SBA, 2016), that for a small business to be deemed successful it must be able to sustain its profitable existence beyond five (5) years of launch. Economic resources capable of ensuring business survival and creating competitive advantages for a business firm, as affirmed in extant literature, must be rare, valuable, inimitable and non-substitutable (Barney, 1986; Habbershon and Williams, 1999; Barney et al., 2001). Survival of such business firm is also a function of certain leadership qualities which includes judgement, perseverance, industry knowledge as well as experience (Say, 1803). The successful firm must possess superior abilities to transform business plan into reality, specialised abilities via extensive knowledge of the specific trade and a good understanding of the leadership qualities required. These abilities, as expressed by Marshall (1890) depend on family background, experience, volume of internal capital, level of education and talent, through which a firm maintains its competitive advantage, continuous improvement of market share and consequently ensure its survival.

Corroborating these views, Schumpeter (1934) posited that the survival of a business depends on its ability to constantly innovate. And that successful innovation is a function of good leadership with strong and scarce motivations from both staff and management. Similar view expressed in the 2016 Pwc survey as reported by Harland (2017) highlighted five (5) critical factors for family business survival. These include fostering workable succession plan for stability; imbibing professionalism in operation; developing strategic planning that encourages radical innovation; encouraging business innovation; and embarking on concerted efforts to prepare the next generation for leadership roles. Thus, the common position across ages rest on the ability and capability of family firms to be creatively innovative to ensure their survival.

Business innovation is about creating more effective processes, generating and implementing new ideas, improving dynamic product qualities and services, as well as effecting positive changes in the business model, reference to existing environment, to deliver improved values. A very important step towards business survival is to constantly scan the market environment, to enable firms generate good ideas to respond to changes in the marketplace, improve productivity, efficiency and remain competitive. As posited by Leenen, (2005), innovations are the expression of entrepreneurial activity that allows a firm to increase its return on investments, achieve greater market share, and strengthen its overall competitive position while contributing to its long-term survival. It is about the introduction of new products, new services, new processes, the opening of new markets, the creation of a neworganization within an industry, or the monopolization of a new source of raw material, all with superior capability to challenge the status quo in the marketplace, while giving the entrepreneurs competitive advantage. (Autio, et al., 2014; DorinandAlexandru; 2014). 
In today's turbulent business environment, where consumers are becoming generally aware of vital market information and demanding improved qualities for their money, it is becoming herculean tasks for business firms to survive. Thus, the assertion that more than 50\% of small businesses in the US do not survive beyond 5 years (SBA, 2016), still holds sway. While most globally transgenerational family businesses are noted to be in their third generation, in the frontier countries like Nigeria, as observed by the PWC, 2018 Report, only 13\% of Nigerian family businesses have a robust, formalised succession plan in place. However, the long-term orientation of family businesses, their resilience and sustainability may only be explained by their penchant for innovation. It is on this premise this study examined the contribution of entrepreneurship innovation to the survival of family businesses in southwestern Nigeria.

\subsection{The Family Business}

In their seminal study on the family embeddedness in entrepreneurship, Aldrich and Cliff (2003) posited that families and businesses are inextricably intertwined, with highly interrelated dynamics. A family business is that in which there is high level of control by family members realised through voting rights, a concentration of family-owned wealth in a single firm and in undiversified manner and the often long-shared history coupled with socio-emotional endowments which focus their attention to both the financial and non-financial goals (Anderson et al. 2003; Duran et al. 2014; Zellweger, et al. 2012). It is an organisation that is greatly influenced in its operation and focus by a successful generation of a family, related biologically or by adoption. The high levels of family control, as noted by Chrisman and Patel (2012); Gomez-Mejia et al. (2007); andKonig et al. (2013) are realized, for instance, through voting rights, managerial involvement, and/or family values andculture. And as posited by Adele et al. (2020), a family business is a commercial entity actively owned and managed by one or more members of a family with the ability to influence the vision and pursue specific goals for the business. They are created primarily to provide employment, generate income and ensure wealth accumulation for the family. However, they have since expanded to include some of the largest companies in the world with serious economic impact on national economies.

Economic importance of family businesses to the growth and development of economies across contexts have been felt centuries ago, and they continue to be vital engines of growth to most economies till date. As reported by the Family Firm Institute (2016), family businesses account for above $80 \%$ of all businesses in the world, contributing more than $75 \%$ of GDP, employing about $80 \%$ of the world working population. In the United States, they accounted for about $90 \%$ of all registered businesses, contributing some $60 \%$ of the GDP, generating about $80 \%$ employment opportunities while consistently making one-third of Fortune 500 companies (Family Firm Institute, 2016). In the United Kingdom, Family businesses accounted for some $87 \%$ of all private sector firms, $36 \%$ of total employment, with a turnover of 1.3trillion-pound sterling, contributing some 418 billion pounds to GDP while paying some 125 billion pounds in taxes, all as at 2014 (Institute for Family Business, 2015). Similar development in China (Family Firm Institute (2016) report revealed that $84.5 \%$ of private firms are family owned, contributing greatly to the GDP, generating employment and contributing to the growth of the economy through tax payments. In Nigeria, as in other frontier countries, where there are no authentic statistic records, family businesses are equally contributing their quota to the growth and development of different economies in terms of GDP, employment opportunities as well as tax payments.

Research works in the area of family business have been observed to emanate mostly from Europe, America and Asia. Scholarly research in the area of family business innovation is generally lacking (Leenen, 2005). And as observed by Kraus, et al. (2012), as at 2011, the SAGE-published Family Business Review (FBR) can only boast of 3 articles with innovation mention out of 23 volumes in its stock. In the frontier countries like Nigeria, the very few numbers of published articles are devoid of empirical foundations, mostly dwelling on problems and prospects. Thus, this paper attempt to examine the contribution of entrepreneurship innovations to the survival of family businesses in the study area that enable them to fulfil their long-term orientation while maintaining family culture and tradition. It should however be noted that, in general terms, academic forays into innovation prowess in family business have been on the increase recently, but outcomes have been largely varied and inconclusive.

A high proportion of findings indicated a negative relationship between family business and entrepreneurship innovation in terms of research and development (R\&D) investments. The Economist (2009) described family business as traditional, usually employing conservative strategies, and shying away from seeking new opportunities. They are slow in decision-making, risk-averse, slow-growing, less entrepreneurial as they are always sluggish in reacting to environmental changes (Cabrera-Sua'rez et al. 2001; Carney 2005; Habbershon et al. 2003; Lubatkinet al. 2007; Morris 1998). At the same time, a considerable number of research works conclude that family businesses are rather highly innovative, which account for their persistence in the market space for decades on-end. Forbes (2014) reported that more than $50 \%$ of most innovative large firms in Europe are family businesses. While they cannot boast of higher research and development (R\&D) budget, family business is more efficient in their innovation processes, they get more innovative output per dollar in terms of number of new products/services, number of patents as well as new product/service revenue generated. (Duran and Zellweger, 2017; Kammerlander and Essen, 2017). Also, that their conservativeness ensures sound investments as part of the broader business strategy (Botha, 2020). Similarly, Simon, et al. (2011) emphasised resource orchestration of family businesses, through which they deploy valuable firm-specific tacit knowledge with superior access to feedback from a trusted external network. These enable them to obtain efficient level of conversion process leading to high levels of innovation outputs ((Adams, et al. 2006).

Family firms tend to be very cautious and prudent about innovation spending. Their long-term relationship with the firm, good understanding of the industry and shareholders ensure they have very deep knowledge of the business environment. They are noted for their family-like culture of maintaining very close relation with the organisation, frequent communication with stakeholders, including clients, employees, suppliers and customers, from where they get the much- 
needed feedback through which they develop creative ideas for new value propositions that endear them to their customers (existing and potential). In another development, some scholarly studies conclude that innovative behaviours of family firms are not homogeneous, and that the occupier of the Chief Executive position determines to a great extent the innovativeness of the firm (Alexie, et al. 2011; Crossan and Apaydin, 2010; Miller, et al. 2011; Vaccaro, et al. 2012). A firm with family member as the CEO is believed to incur less expenditure on innovation but have higher innovation output due to the conversion rate attribute of a family culture. Where the CEO is the founder, result shows a higher investment spending with a higher innovation output - this as a result of the founder's penchant for aggressive radical innovation to achieve his market share expansion and firm growth desires. However, this is not so for later generation CEOs as the objective is to maintain their family's hold on the business, they tend to be more cautious and less willing to invest in uncertainty (Alexie, et al. 2011; Crossan and Apaydin, 2010; Miller, et al. 2011; Vaccaro, et al. 2012). Also, where the CEO is a non-family member, the tendency is to invest more on uncertainty, with aggressiveness for firm growth. However, the resulting innovation output tends to be lower than the cautious approach of the family CEOs (Finkelstein \&Hambrick, 1990; Miller et al. 2013).

\subsection{Entrepreneurship Innovation in Family Business}

Innovation can be described as a processinvolving changes in product offerings, services, business model, or operations that meaningfully improves the experience of a large number of stakeholders. It must be meaningful, in that an invention must be new, creative and positively impact large number of stakeholders with significantly improved value over existing standards. As noted by Drucker (1985), innovation is the specific tool of entrepreneur through which they exploit changes as opportunity for a different business or service. It is increasingly seen as a powerful way of seeing competitive advantage and a more secure approach to defending strategic position that guarantee business success/survival. Similar view by Adele and Afolabi (2020) stated that innovation is a means of exploring business opportunities through new combination of resources to produce better goods and services with higher value propositions that are presented to the market in a more creative manner. Barney (1991), in the Resource Based View theory, postulated that the stimulus responsible for growth and performances are within the internal firms' capabilities. While the sources of a firm's capabilities are the resources including capital, assets, geographical location, networks. And for family businesses, it also includes traditions, orientation, values, culture, family name, reputation, relationship, tacit knowledge, loyalty and trusts (Barney, 1991).

Extant literature is of the consensus that the main drivers of firm's innovation are the firm-level resources (especially, financial), firm-level slack resources (deployable to various uses), and inter-firm level resources of firm networks and collaboration, especially on R\&D (Bierly et al. 2009; Chen et al. 2012; Wang and Li Yin, 2015). It is the ability to recombine these resources in strategic manner that forms a firm's capability in terms of competencies and invisible assets through which it develops competitive advantage. And as posited by Aldrich and Cliff (2003); Herbbashon and Williams (1999), family businesses acquire, leverage and anchor on their resources in such a way as to achieve their longterm orientation, goals, sustainability - even during critical periods, resilience, tacit knowledge, family culture, all culminating in an invaluable organisation culture that engender trust, loyalty and socio-cultural and economic stability. And as posited by Tidd and Bessant (2011), innovation is not just about new product/service - it also includes improving existing ones through combinations and/or recombination of resources to raise value offerings. This is about effecting positive changes that engender positive transformation, bringing about a better and more beneficial ways of utilizing available resources and getting the best of them. Entrepreneurial firms, as posited by Schumpeter (1934) and robustly defined by Tidd and Bessant (2011), do leverage on the four broad categories of innovation, which include: product innovation - the superior ability to change and improve value offerings;process innovation - changes in the method of production effected by producers to improve their offerings and gain competitive advantage in the marketplace;position innovation - changes in the perception of an established product/service that leads to appreciable improvement in its degree of acceptability by consumers; and paradigm innovation - the superior ability to change the underlying model (the way and manner a product is utilized or engaged) as well as changes in its conceptual mode of operations. All of these in order to maintain relationship with existing customers while winning potential ones to improve their market share.

\subsection{Family Business in Nigeria}

Historically, family businesses have long been part and parcel of Nigerian business life. As it happens across contexts, family business constitutes the greater proportion of business firms in Nigeria, and their advent is dated back to before independence. While a number of these firms that sprung up early are no more in existence, quite a high proportion are able to weather the storm and are waxing stronger today. They are not only able to innovatively create acceptable value propositions in terms of products and services; they leverage on credible feedback to improve their value offerings. From the days of Pa SoboyejoOdulate, who produced 'Alabukun' - an analgesic, in 1918, the same year of launch of Aspirin-caffeine in the US, and who later ventured into various expansion including Patent Medicine Stores in 1920 growing them across southwestern Nigeria. As reported by Edward-Ekpu (2018), Pa Odulate invoked the spirit of process innovation to establish Alabukun clinic in Abeokuta in 1923, from where he utilised the drug together with AlabukunMentholine to manage his numerous patience. In the spirit of product innovation, he invented sales of his products in sachet - that target the 'bottom of the pyramid' market.

The Ibru Business Dynasty also debuted as frozen fish distributor in 1956 through Freshwater Fishing Company Limited. On the accounts of Forrest (1994) and Ogbor (2009), the company leveraged on paradigm innovation to acquire first fishing boat in 1963, 3 freezer trawlers in 1965, which grew to 25 freezer trawlers as at 1970. As a very innovative family business, it leveraged on position and paradigm innovation to establish a transport company out of some 200 
vehicles in its stock, through which it hitherto distributes frozen foods, to render other transport services. The business has since continued to grow till date with serious economic impact in shipping, agriculture, aviation, banking, brewery, construction, hospitality, oil and gas, real estate as well as tractor leases and sales.

Another prominent family dynasty is the Honeywell Group that debuted as miller and processor of wheat-based products in 1972. Leveraging on both product and process innovations, it employs its prowess to utilise other raw materials like corn to produce corn-mill, soyabeans for cerolina, wheat-flour for semolina, wheatmeal, spaghetti, etc. The company has since ventured into various sectors of the Nigerian economy including engineering designs, oil and gas, hospitality, tourism, energy supplies (off-grid, fossil-fuel and renewable), real estate, where it engages innovations for performance successes (Agekameh, 2019 and Komolafe, 2019). The astounding success of these business network earned the progenitor, Oba Otudeko, the Federal Government of Nigeria's Productivity Award in 2019.

Mention must be made of other family businesses spanning decades and making outstanding contributions to the economic development of Nigeria to include The Dantata Group of companies, which started as kolanuts, beeds and groundnut exporting businesses also in the 1950s, today, the baton is held by AlikoDangote, Forbes richest Blackman in the world (Mfonobong, 2020). He came into prominence through bulk importation of cement and through product innovation established cement production plant and expanded the scope to service most of the West African markets. He has innovatively extended the tentacle of the family business into several fronts and making serious progress. The AdebolaAdegunwa Group, founded in 1970s, owner of Ess-Ay Holdings - started making waves in fast foods manufacturing, it later invoked the spirit of position innovation to venture into soft drinks production that compliments its initial offerings, through which it introduced fast food joints - Rite Foods Limited across southwestern Nigeria. In a similar development, the Adegunwa Group established Fototek Industries in 1980, with some 26 branches across southwest Nigeria by the year 2000 (Osewa, 2020). Applying position innovation, the Group ventured into prints specialities including web designs, multimedia presentations and event marketing. Others are the Ibeto Group, Adenuga Family, IsyakuRabiu and Sons, Mai Deribes Venture, Bank Anthony, Folawiyo, Mike Adenuga, Eleganza Group, Doyin Group, to mention but few.

While the collapse of many early birds in the field of family business in Nigeria were usually attributed to succession plans gone wrong, a cursory look into individual dynasty might not support this general notion. The demise of erstwhile Nigerian business dynasties like that of the Odutola Business Empire, Fajemirokun Group, Concord Group, EkeneDilichukwu, to mention a few, might be as a result of some complex contradictions to which serious research may be needed to figure out. Though, most family-owned firms are said to collapse as a result of poor succession plans or lack of it, but the inability of firms to constantly scan their business environment, adapt to changes, diversify and utilise their resource capabilities to maintain competitive advantage can spell doom for them.

\section{Methodology}

The study was conducted on twenty-five (25) purposively selected family businesses that have been in existence for more than five decades in the Southwestern Nigeria. Random sampling technique was used to select 20 respondents from each firm comprising of admixture of management and senior officers of identified family businesses. Incidental sampling technique was used to select five (5) CEOs for personal interview, since some of them pleaded to have someone else represent them. Primary data for the study were gathered through personal interviews on CEOs of sampled business firms, whilestructured questionnaires, with a set of multiple-item reflecting a 5-point Likert scales to measure each identified variable, were administered to elicit information from respondents. A total of 433 responses, out of 500 questionnaires, were retrieved and utilised for data analysis after screening and evaluation, representing 86.6\% response rate. Data obtained were analyzed with the aid of descriptive statistical tools to describe innovation capabilities of family businesses as a factor of their long-term survival.

\section{Results and Discussion}

The purpose of the study was to examine factors responsible for the long-time survival of family businesses. Specifically, the study examined the contribution of entrepreneurship innovation into the achievement of long-term orientation of family businesses, most especially in south-western Nigeria. Consideration was given to the nature and extent of economic resources at their disposal coupled with their passion for preserving the family legacies. It is in this respect, results of descriptive statistical tools deployed to analyse data obtained through questionnaires administered (Table 1) and the qualitative data gathered through personal interviews conducted on sampled CEOs were compared for the purposes of literal and analytical generalizations. 


\begin{tabular}{|c|c|c|c|c|c|}
\hline Particulars & $\begin{array}{l}\text { Strongly } \\
\text { Agree }\end{array}$ & Agree & Undecided & Disagree & $\begin{array}{l}\text { Strongly } \\
\text { Disagree }\end{array}$ \\
\hline $\begin{array}{c}\text { Family businesses are traditionally } \\
\text { conservative, shying away from seeking } \\
\text { new opportunities }\end{array}$ & 13.25 & 8.33 & 12.35 & 22.35 & 43.72 \\
\hline $\begin{array}{c}\text { Family businesses are always reluctant to } \\
\text { invest in R \& D }\end{array}$ & 12.05 & 12.75 & 17.25 & 20.70 & 37.25 \\
\hline $\begin{array}{l}\text { Family businesses are usually closed to } \\
\text { external knowledge that spur innovation }\end{array}$ & 10.32 & 8.30 & 10.25 & 30.53 & 40.60 \\
\hline $\begin{array}{c}\text { Family businesses are comfortable with } \\
\text { incremental innovation }\end{array}$ & 10.40 & 9.5 & 19.15 & 23.40 & 38.55 \\
\hline $\begin{array}{c}\text { Family businesses are less } \\
\text { entrepreneurial, sluggish in reaction to } \\
\text { environmental changes }\end{array}$ & 15.20 & 8.80 & 14.80 & 26.32 & 34.88 \\
\hline $\begin{array}{c}\text { Family businesses are slow in decision } \\
\text { making and slow growing }\end{array}$ & 10.20 & 12.70 & 16.25 & 24.05 & 36.80 \\
\hline $\begin{array}{c}\text { Family businesses are endowed with } \\
\text { economic resources capable of ensuring } \\
\text { business survival }\end{array}$ & 42.8 & 25.45 & 17.20 & 7.65 & 6.90 \\
\hline $\begin{array}{c}\text { Family businesses possess rich industrial } \\
\text { knowledge and experience to ensure } \\
\text { sustainability }\end{array}$ & 44.25 & 24.40 & 14.23 & 5.05 & 12.07 \\
\hline $\begin{array}{c}\text { Family businesses proximity to } \\
\text { stakeholders afford them quality } \\
\text { feedbacks through which they generate } \\
\text { creative ideas for innovation }\end{array}$ & 45.35 & 22.65 & 13.20 & 8.60 & 10.20 \\
\hline $\begin{array}{l}\text { Family business' ability to improve value- } \\
\text { propositions endear them to their } \\
\text { customers }\end{array}$ & 45.76 & 22.34 & 15.30 & 7.20 & 9.40 \\
\hline $\begin{array}{l}\text { Long-term orientation is sustainable only } \\
\text { through innovative R \& D investments }\end{array}$ & 42.35 & 23.64 & 15.86 & 7.65 & 10.50 \\
\hline $\begin{array}{c}\text { Family businesses are very prudent in } \\
\text { investment and more efficient in } \\
\text { innovation processes }\end{array}$ & 43.32 & 23.55 & 13.78 & 5.95 & 13.40 \\
\hline
\end{tabular}

Table 1: Respondents Responses on Factors Influencing Innovation as Survival

Strategy of Family Businesses in Nigeria

Source: Field Survey, 2020

The results obtained, as shown in Table 1(Appendix 1) revealed that most of the sampled respondents (66.07\%) disagree that family businesses are traditionally conservative and that they always shy away from seeking new opportunities. This is considered a major shift from hitherto general believe that family businesses are less innovative and docile. This result was supported wholly by the analysis of data of the interviewees, as the textual descriptions from three participants summarized their responses as presented:

- $\quad$ Participant A:Yes, we may be conservative in our approach, but that does not mean lack of innovativeness. To me, it might be we are always cautious to insist on only prudent R\&D investments. And to the best of my knowledge, we get the best outputs from our R\&D activities.

- $\quad$ Participant C:That cannot be true, how else have we been able to remain in the market, maintaining our market share, by introducing new products and services as well as venturing into several other sectors of the economy since 1956 ?

- $\quad$ Participant E: Perhaps our conservative nature is paying off after all. What we need in business is to be cautious and calculative. Investment in R\&D is needed when environmental scanning suggests it, and we always envisage it to direct our investment expenditure.

This position is corroborated by (Botha, 2020; Duran and Zellweger, 2017; Kammerlander and Essen, 2017), who stated that while family businesses cannot boast of higher research and development (R\&D) budget, studies show that they are more efficient in their innovation process, they get more innovative output per dollar in terms of number of new products/services, number of patents as well as new product/service revenue generated.

Table 1 also revealed that a large proportion of sampled respondents (71.13\%) disagree that family businesses are usually closed to external knowledge that spur innovation. The result negates the general believe that decision-making is strictly made a family affair and that they always make do with the limited resources at their disposal which can limit their growth trajectory. The analysis of data of the interviewees also corroborates this result, as the textual descriptions from three participants summarized their responses as presented: 
- Participant A:I disagree with that notion, it does not mean every staff is a family member, we may be holding higher proportion of the company shares. Don't forget that as business firms we have stakeholders like customers, supplier, employees. We are not in anyway closed to external knowledge.

- Participant B:In fact, our family culture ensures we maintain very close relations with every stakeholder, including current and ex-staff, friends and other family members from where we obtain quality feedback information through which we develop value propositions to continuously satisfy our markets.

- Participant E:No, we are very open to our environment, remember we have come a long way, that is how we get trendy. We always maintain close relationships with every stakeholder, it's the results of our closeness with them that we determine ahead of market what direction their tastes are likely to change

This position is further reinforced by recent studies (Adams, et al. 2006 and Simon, et al. 2011) that emphasised the resource orchestration of family business, through which they deploy valuable firm-specific tacit knowledge with superior access to feedback from a trusted external network. These enable them to obtain efficient level of conversion process leading to high levels of innovation outputs.

To the question that family businesses are comfortable with incremental innovation, Table 1 shows that a large proportion of sampled respondents (61.95\%) disagree. That they do pursue serious changes to the way they effect production of goods and services and that is the only way they can still be waxing stronger in the market. This result was supported by the analysis of data of the interviewees, as the textual descriptions from three participants summarized their responses as presented:

- Participant B:Whoever says that is underestimating the values and the business prowess of family business. History is replete with how family firms are leveraging on innovations across contexts. We started from frozen fish distribution in the 1950s, ventured into industrial fishing deploying trawlers and today we are into several economic sectors including agriculture, aviation, hospitality, oil and gas, etc. making serious impacts. Ours is radical innovation per excellence.

- Participant C:I disagree with that assertion, before you can say that, comparative analysis is needed to determine innovation outputs across firms. Here, we can boast of greater, more efficient innovation processes measured by number of new products, new ventures, patents and revenues generated from our new products.

- Participant D:No, not at all. What we call family businesses are usually firms with long years of experience, with very deep knowledge of the industry, the firm and the stakeholders. The experience and knowledge so acquired is enough to guide our innovation-propelled diversification investments across sectors.

The result is in consonance with the studies of Aldrich and Cliff (2003); Colli (2003), that family business pervasiveness all over the world is unrivalled and that they are the most prevalent form of business characterising all business sectors from micro, small, medium and large firms. Also, that their doggedness in the pursuit of operational excellence ensures successful diversification into various sectors of an economy (Davis, 2020). Thus, they must be alive to their responsibilities of constantly innovating to meet the always changing needs of their customers.

Table 1 also revealed that a large proportion of sampled respondents (61.2\%) disagree that family businesses are less entrepreneurial, sluggish in reaction to environmental changes. This is another misrepresentation the result is out too clear as inability of any firm to anticipate environmental changes in order to adapt will ensure it does not survive. The analysis of data of the interviewees also agrees withthe result, as the textual descriptions from three participants summarized their responses as presented:

- Participant A:This I belief is a misconception, on the contrary, we usually take a long-term view of investments and relationships with a view to focus on persistent improvement via innovation. And it pays off, perhaps that is the more reason we have come this far.

- Participant B: No, we are very entrepreneurial. It is part of business strategy to first search for growth opportunities from within our industry, where we are conversant, its only when we have exhausted such that we spread out our tentacles. The proof is here, from being a distributor, we acquired trawlers, establish transport company, venture into motor/tractor dealing. Now into oil and gas, hospitality, tourism, how else do you describe entrepreneurship?

- Participant D:What you refer to as conservativeness is perhaps our penchant for the pursuance of operational excellence. Mark you, we as family businesses must pursue long-term objectives of maintaining good relationships with our loyal stakeholder, while building key talents in select individuals. All these take time and requires doggedness.

This result is in tandem with Adams et al (2006); and Simons et al (2011), whose studies supported the fact that family businesses emphasise resource orchestration by the deployment of valuable, firm-specific tacit knowledge as well as superior access to feedback from a trusted, external network resulting in efficient conversion process and ultimately high levels of innovation output, such as new product launches.

Table 1 also revealed that a large proportion of sampled respondents (68.25) agree that family businesses are endowed with economic resources capable of ensuring business survival. This agrees with all the interviewees, the textual descriptions of three respondents are as expressed below:

- Participant A:This might be because we possess unique resources in terms of our culture, orientation, name, reputation, tacit knowledge, everything is within the family. The close-knit relationship is what we extend to our stakeholders including employees, clients and suppliers.

- Participant B:Our resources are very unique to us, as a family, the business acumen is passed down generations and each successor always try to improve on the level of performance. 
- Participant E:To that I will say it runs in the family, successive leaders must have imbibed a lot of experience from their forbears. And the fact that each one of us intends to sustain the legacy and bestows a better organisation is a sure way to ensure not only sustainability but continuous improved performance.

The result corroborates the submissions of Duran and Zellweger, 2017 and Kammerlander and Essen, 2017 that entrepreneurial families concentrate their wealth in one or few firms, using their shareholder positions to ensure close relationships with a handful of partners. And that from suppliers to customers, these firms can harvest information to develop creative ideas leading to novel processes and products while ensuring prudent investments.

Table 1 also revealed that a large proportion of sampled respondent (68.65\%) agree that family businesses possess rich industrial knowledge and experience to ensure sustainability. This as a result of their long relationship with the firm, the industry and the market environment, they are in a better position than start-ups. The analysis of data of the interviewees conforms withthe result, as the textual descriptions from three participants summarized their responses as presented:

- Participant C:Our rich industrial knowledge emanates from our closeness to our business founders who blazed the trail and who graciously share their travails across hierarchical levels openly to the benefit of all. Thus, we do employ our family culture to empower employees through cross-functional meetings to exchange quality ideas.

- Participant D:Sustainability is ensured when family owners actively participate in the innovation process. They draw good quality information from their personal networks including former and current employees, suppliers, clients and other family members and friends outside the firm to enrich the knowledge through which the firm is strengthened.

- Participant E:Yes, our businesses are sustained easily not only because we possess unique resources, but we leverage on our trust-based external networks, building on a wide-spread number of trusted sources when searching for new business models. We can boast of a diverse group of good businessmen friends, our suppliers, academics, internal and external managers, policy makers, etc. who are always willing to share critical information for our development.

The result is in tandem with the studies of Acs et al. (2013); and Block et al. (2011) who concluded that the major reason why some companies survive rapid changes in the environment while others must close their doors is the business knowledge of owner/managers, and that background information was important as one of the important sources of innovative entrepreneurship.

Results from Table 1 also indicated that a large proportion of sampled respondents (68.1\%) agree that family businesses ability to improve value-propositions endear them to their customers. This is the sure way to maintaining market share for any business firm, more so that family businesses have long-term orientation. This result was supported by the analysis of data of the interviewees, as the textual descriptions from three participants summarized their responses as presented:

- Participant B:I agree in totality. There is constant need for the reinvention of our business models in order to realise the full potential of new product innovations, coupled with ability to adapt to changing market requirements. Our customers today are becoming more sophisticated, demanding more value for their monies, and unless a firm is proactive, it will have itself to blame.

- Participant C:Yes, that is the only way we can remain entrepreneurial. We continually engage in product-market innovations with a view to beating our competitors to the punch, this is somehow risky, but we usually reap the maximum benefits afterwards.

- Participant E:Every innovative firm desirous of its profitable survival must constantly review its strategies in line with the dictates of the market. We can only ensure our survival only when we are able to maintain good and cordial relationships with our clients. And this is achievable through our products quality and pricing.

The result is in consonance with the works of Miller and Friesen (1983); Johnson et al. (2008) that affirm that an entrepreneurial firm is one that engages in product-market innovations, undertakes somewhat risky ventures, through new raw materials or new processes and is first to come up with proactive innovations, beating competitors to the market.

\section{Conclusion}

The study investigated the contribution of entrepreneurial innovation to the survival of family businesses. Economic resources capable of ensuring prudent innovative processes have been carefully examined as they have regularly featured across contexts, and especially in southwestern Nigeria. Also examined is the superior ability of sampled firms to leverage on various dimension of innovation to perpetuate themselves and maintain their market share in the marketplace. Findings revealed that family businesses not only embrace entrepreneurial innovation as strategies to accomplish their long-term orientation, but that they exploit the retinue of unique resources at their disposal to maintain strong hold on their market share. The notion that family businesses are traditionally conservative and risk-averse have been countered in this study, instead it is an attribute that describes their cautiousness to avoid wasteful investments which ensure they get more efficient innovative output per dollar invested. Findings also disproved the notion that family businesses are closed to external knowledge that spur innovation, it was rather a unique opportunity to leverage trustbased external network including group of friends, present and former employees, suppliers and other family firm owners through where they obtain critical information for creative ideas for novel products and services.

The entrepreneurial prowess exhibited by most family firms have ensured they develop capacity to conduct market scanning, envisage disruptions in the marketplace, to design best means of adapting to changes. They must be entrepreneurial to leverage on both backward and forward linkages in their expansionary bids that most often compliments their initial offerings thereby improving their overall value offerings that endear them to their customers. 
Also, their ability to obtain good quality feedback from their networks is an indication that they are very open to external influences from where quality information is derived for their performance improvement.

On the whole, the power of effective control, as demonstrated by most family firms, has proven to be a necessary ingredient that flows from ownership of investment capital. And where superior abilities derivable from the knowledge of the firm, the industry and the market environment are transferred through family background, it usually results in successful implementation of the process where creative ideas are prudently and effectively converted within an organisation. These are about the strategic orientation capable of providing ways for firms to adapt to technology, competition and market changes that enable them to pursue their long-term survival keeping them competitively innovative in business.

\section{References}

i. Acs, Z. J., Audrestch, D. B., and Lehmann, E. E. @013). The Spillover Theory of Entrepreneurship. Small Business Economics 41: 757 - 774 https://doi.org/10.1007/S 11187-013-9505-9

ii. Adams, R., Bessant, J., and Phelps, R. (2006). Innovation Management Measurement: A Review.International Journal of Management Reviews, 8(1): 21-47.

iii. Adele, H. A., Agboola, J. A., Onibon, M. T. G., Shokefun, E. A., and Babatunde, D. (2020). An Evaluation of Gender Equality in Family Business Succession in Southwestern Nigeria. Gender and Behaviour 18(2) www.ifepsychologia.org

iv. Adele, H. A. and Afolabi, Y. A. (2020). Entrepreneurship. McPat Publishers, Ado-Ekiti.ISBN 978-978-973-623-2

v. Agekameh, D. (2019). Oba Otudeko: Celebrating an Icon. www.ntionline.net

vi. Aldrich, H. E and Cliff, J. E. (2003). Pervasive Effects of Family on Entrepreneurship: Toward a Family Embeddedness Perspective. Journal of Business Review 18: 573 - 596 www.sciepub.com

vii. Alexiev, A. S., Jansen, J. J., Van den Bosch, F. A., andVolberda, H. W. (2011). Top Management TeamAdviceSeeking and ExploratoryInnovation: The ModeratingRole of TMT Heterogeneity.Journal of ManagementStudies, 47(7): 1343-1364.

viii. Anderson, R. C.,Mansi, S. A. andReeb, D. M. (2003). Founding-family Ownership and the Agency Cost of Debt. Journal of Financial Economics, 68(2): 263 - 285

ix. Autio, E. Kenny, M., Mustar, P. and Siegel, D. S. (2014). Entrepreneurial Innovation: The Importance ofContext. Management of Entrepreneurial Ecosystems. Research Policy 43(7) ～www.doi:10.1016/j.respol.2014

x. Barney, J. (1991). Firm Resources and SustainedCompetitiveAdvantage. Journal of Management,17(1): 99-120.

xi. Barney, J., Wright, M., and Ketchen, D. J. (2001). The Resource-Based View of the Firm: Ten Years After. Journal of Management 27(625): 625 - 641 https://doi.org/10.1177/0149206310200601

xii. Bierly, P.E., Damanpour, F. and Santoro, M.D. (2009), 'The Application of ExternalKnowledge:OrganizationalConditions for Exploration and Exploitation', Journal of Management Studies,Vol. 46(3): 481-509.

xiii. Block, J., Miller, D., Jaskiewicz, P., and Spiegel, F. (2011). Innovation in Founder and FamilyFirms:Entrepreneurial VersusNurturerIdentities of Owners. Frontiers of EntrepreneurshipResearch, 31(13): 437-450.

xiv. https://doi.10.1177/0894486513477454

xv. Botha, F. (2019). The 5 Cs of Family Business Success. Forbes. https://www.forbes.com

xvi. Cabrera-Suarez, K., Saa-Perez, P., and Garcia-Almeida, D. (2001). The SuccessionProcess from a Resource- and Knowledge-based View of the FamilyFirm. Family Business Review, 14(1): 37-48.

xvii. Carney, M. (2005). Corporate Governance and CompetitiveAdvantage in Family-controlled Firms.Entrepreneurship Theory and Practice, 29(3): 249-265.

xviii. Chen, C.J., Huang, Y.F. and Lin, B.W. (2012), 'How FirmsInnovatethroughR\&DInternationalization?An S-curve Hypothesis', Research Policy, 41(9): 1544-1554.

xix. Chrisman, J. J., and Patel, P. (2012). Variations in R\&D Investments of Family and Non-Family Firms: BehaviouralAgency and MyopicLossAversion Perspectives. Academy of ManagementJournal, 55(4): 976-997.

xx. Colli, A. (2003). Family Firms in Britain, Spain, and Italy in the Nineteenth and Twentieth Centuries. Enterprise and Society 4(1): 28 - 64 https://www.jstor.org/stable

xxi. Crossan, M. M., andApaydin, M. (2010). A Multi-dimensional Framework of OrganizationalInnovation: A SystematicReview of the Literature. Journal of Management Studies, 47(6):1154-1191.

xxii. Davis, J. A. (2020). What Makes Family Business Lasts? Managing Organisations. Harvard Business Review https://www.hbr.org

xxiii. Dorin, C., and Alexandru, G. S. (2014). Dynamics of the Entrepreneurship concept. Literature Review. Annals of Faculty of Economics, 1(1): 445 - 451 https://www.semanticsholar.org

xxiv. Drucker, P.E., (1985). Innovation and Entrepreneurship: Practice and Principles. Harper \& Row, New York.

xxv. Duran, P. and Zellweger, T. (2017). Innovation in Family Businesses. Forbes https://www.forbes.com

xxvi. Duran, P., Kammerlander, N., Marc van Essen, and Zellweger, T. (2014). Doing More with

xxvii. Less: Innovation Input and Output in Family Firms. Academy of Management Journal 47(1): 1 - 76

xxviii. Economist. (2009). Dynasties and Durability. The Economist Daily Newspaper.

xxix. http://www.economist.com/node/14517406.

xxx. Edward-Ekpu, U. (2018). The Untold 100-year old Story of Nigeria's First Homegrown Modern Drug. Quartz Africa Media Inc. https://www.qz.com 
xxxi. Finkelstein, S., andHambrick, D. C. 91990). Top Management-team Tenure and Organizational Outcomes: The ModeratingRole of ManagerialDiscretion. Administrative Science Quarterly,35(3): 484-503.

xxxii. Forrest, T. G. (1994). The Advance of African Capital: The Growth of Nigerian Private Enterprise. Edinburg University Press. ISBN 0-7486-0492-8

xxxiii. Gomez-Mejia, L.R., Haynes, K.T., Nunez-Nickel, M., Jacobson, K.J.L. and Moyano-Fuentes, J. (2007). 'SocioemotionalWealth and BusinessRisks in Family-controlled Firms: Evidencefrom SpanishOlive OilMills', Administrative Science Quarterly (1): 106-137.

xxxiv. Habbershon T. G., Williams, M. (1999). A Resource-based Framework for Assessing the StrategicAdvantagesof FamilyFirms. Family Business Review 12(1):1-25

xxxv. Habbershon TG, Williams M, MacMillan I (2003). A Unified SystemsPerspective of FamilyFirm Performance. Journal of BusinessVenture 18(4):451-465

xxxvi. Harlan, D. (2017). Family Business Survey 2016 Report. https://www.pwc.com

xxxvii. Jean-Baptistse Say (1803). A Treatise on Political Economic: The Production, Distribution and Consumption of Wealth. Cambridge University Press. ISBN 067800025X LCN 6323524

xxxviii. Johnson, M. W., Christensen, C. M., andKagerman, H. (2008). Reinventing Your BusinessModel. Harvard Business Review 86(12):51-59

xxxix. Kammerlander, N., Marc van Essen (2017). Family Business Innovation. Forbes. https://www.forbes.com

xl. Komolafe, B. (2019). Oba Otudeko: 'Lifetime of an Entrepreneur'www.vanguardngr.com

xli. Konig, A., Kammerlander, N., and Enders, A. (2013). The FamilyInnovator'sDilemma: HowFamily InfluenceAffects the Adoption of DiscontinuousTechnologies by IncumbentFirms. Academy of Management Review, 38(3): 418441.

xlii. Kraus, S., Fink, M., Harms, R. (2012). Family FirmResearch: Sketchinga ResearchField. International Journal Entrepreneurship Innovation Management 13(1):32-47

xliii. Leenen, S. (2005). Innovation in FamilyBusinesses- AConceptualFramework with Case Studies of Industrial FamilyFirms in the German "Mittelstand". St. Gallen, HSG

xliv. Lubatkin, M. H., Ling, Y., and Schulze, W. S. (2007). An OrganizationalJustice-based View of Self-control and AgencyCosts in FamilyFirms. Journal of Management Studies 44(6): 955 - 971

xlv. Marshall, A. (1890). Principles of Economics. Palgrave Macmillan's 978-1-137-37526-1

xlvi. Miller, D., Friesen, P. H. (1983). Innovation in Conservative and EntrepreneurialFirms: Two Models of Strategic Momentum. Strategic Management Journal 3(1):1-25

xlvii. Miller, D., Le Breton-Miller, I., and Lester, R. H. (2013). Family FirmGovernance, StrategicConformity, and Performance: Institutional vs. StrategicPerspectives. Organization Science,24(1): 189-209. 24(1): 189-209.

xlviii. Miller, D., Le Breton-Miller, I., and Lester, R. H. (2011). Family and Lone FounderOwnership and StrategicBehaviour: Social Context, Identity, and InstitutionalLogics. Journal ofManagement Studies, 48(1): 1-25.

xlix. Mfonobong, N. (2020). AlikoDangote: Africa's Richest Man. Forbes https:// www.forbes.com

l. Morris, M. H. (1998). Entrepreneurial Intensity. ABC-CLIO, Westport, USA ISBN: 9780899309750

li. Ogbor, J. O. (2009). Enterprises in Sub-Sahara Africa: A Strategic Management Perspective. Author House. ISBN 14389-3392-4

lii. Osewa, O. (2020). The Challenge of Creating Successful Nigerian Products. https://www.pulse.ng/news

liii. SBA (2016). Survival Rates and Firm Age. US Small Business Administration, Office of Advocacy. https://www.sba.gov/advocacy

liv. Schumpeter, J., 1934, TheTheory of EconomicDevelopment, Harvard University Press, Cambridge. Editura YTPREE, Cluj-Napoca.

lv. Singla, C., Veliyath, R., and George, R. (2013). Family Firms and Internationalization-Governance Relationships: Evidence of SecondaryAgency Issues. StrategicManagement Journal, 35(4):606-616.

lvi. Sirmon, D. G., Hitt, M. A., Ireland, R. D., and Gilbert, B. A. (2011). Resource Orchestration to CreateCompetitiveAdvantageBreadth, Depth, and LifeCycleEffects. Journal of Management,37(5): 1390-1412

lvii. Vaccaro, I. G., Jansen, J. J., Van Den Bosch, F. A., andVolberda, H. W. (2012). Management Innovation and Leadership: The ModeratingRole of OrganizationalSize. Journal of Management Studies, 49(1): 28-51.

lviii. Wang, Y. and Li-Ying, J. (2015). Licensing Foreign Technology and the Moderating Role of Local R\&D Collaboration: Extending the Relational Review. Journal of Product Innovation Management 32(6): 997 - 1013

lix. Zellweger, T. M., Kellermanns, F. W., Chrisman, J. J., and Chua, J. H. (2012). Family Control and FamilyFirmValuations by Family CEOs: The Importance of Intentions for Transgenerational Control. Organization Science, 23(2): 851-868. 